\title{
Influence of atmospheric forcing parameters on modelled mountain permafrost evolution
}

Markus Engelhardt, Christian Hauck and Nadine Salzmann

\author{
Markus Engelhardt: \\ Department of Geosciences, University of Oslo \\ P.O. Box 1047 Blindern, 0316 Oslo, Norway \\ phone: +47 22857251 \\ e-mail: markus.engelhardt@geo.uio.no \\ Christian Hauck: \\ Department of Geosciences, University of Fribourg \\ Switzerland \\ Phone: +41 263009011 \\ e-mail: christian.hauck@unifr.ch \\ Nadine Salzmann: \\ Department of Geosciences, University of Fribourg \\ Switzerland \\ Phone: +41 263009250 \\ e-mail: nadine.salzmann@unifr.ch
}


Abstract

To evaluate the sensitivity of mountain permafrost to atmospheric forcing, the dominant meteorological variables such as temperature, precipitation and timing and duration of snow cover have to be considered. Simulations with a one-dimensional coupled heat and mass transfer model (CoupModel) are used to investigate the interactions between the atmosphere and the ground focusing on ground temperature evolution and the temporal variability of the depth of the unfrozen top layer in summer (active layer depth). Idealised and observed atmospheric forcing data sets are used to determine the meteorological conditions, which show the largest impact on the permafrost regime. Borehole temperature and energy balance data from the permafrost station Schilthorn (2900 m asl, Berner Oberland) are used for verification. The results for the Schilthorn site show the largest impact due to summer temperatures changes during the snow free period and to a lesser extent winter precipitation which influence the duration of the snow cover. Similarly important is the timing of the first snow event in autumn which leads to a sufficiently large snow cover to isolate the ground from atmospheric forcing. Simulations with different data sets from Regional Climate Model (RCM) simulations derived from an ensemble of models and scenarios show that the differences in changes of active layer depth between different RCMs are on the same order than between different scenarios. 


\section{Zusammenfassung}

Um die Empfindlichkeit von Gebirgspermafrost auf atmosphärischen Einfluss zu untersuchen, müssen die bestimmenden meteorologischen Größen wie Temperatur, Niederschlag, Zeitpunkt und Dauer der Schneebedeckung berücksichtigt werden. Simulationen mit einem eindimensionalen gekoppelten Wärme- und Massentransportmodell (CoupModel) werden verwendet, um die Wechselwirkung zwischen der Atmosphäre und dem Boden zu ermitteln, wobei auf die Bodentemperaturentwicklung und die zeitlichen Schwankungen der ungefrorenen obersten Schicht im Sommer (Auftauschicht) konzentriert wird. Idealisierte und beobachtete Daten von atmosphärischen Antriebsgrößen werden verwendet, um die meteorologische Bedingungen zu bestimmen, die den größten Einfluss auf den Permafrost aufweisen. Bohrlochtemperaturdaten und Energiebilanzdaten der Permafroststation Schilthorn (2900 m ü. NHN, Berner Oberland) werden zu Kontrollzwecken verwendet. Die Ergebnisse für das Schilthorn zeigen die größte Einwirkung aufgrund von Änderungen der Sommertemperatur während der schneefreien Zeit und zu einem geringeren Ausmaß durch Winterniederschlag, welcher die Zeit der Schneebedeckung beeinflusst. Von ähnlicher Bedeutung ist der Zeitpunkt des ersten Schneefalls im Herbst, der zu einer ausreichend hohen Schneebedeckung führt, um den Boden von atmosphärischem Einfluss zu isolieren. Simulationen mit verschiedenen Zeitreihen regionaler Klimamodelle (RCM), abgeleitet aus einem Ensemble von Modellen und Szenarien, zeigen, dass die Unterschiede der Änderungen der Auftauschicht aus den Ergebnissen der verschiedenen Modelle in der gleichen Größenordnung liegen wie die Unterschiede aus verschiedenen Szenarien. 


\section{1 Introduction}

41 Climate change is not restricted to the atmosphere, it also influences the ground temperature

42 regime. This can be especially important where permanently frozen ground conditions (per-

43 mafrost) with temperatures close to the melting point exist. Permafrost is defined as permanently

44 frozen ground for at least two years (FRENCH, 1996). It therefore exists at depths where the

45 seasonal variations of the temperature stay below the freezing point (WILLIAMS and SMITH,

46 1989). The thickness of the seasonal thaw layer, commonly known as active layer thickness,

47 can show strong year-to-year variations and usually reaches a few metres for typical mountain

48 permafrost occurrences in the Swiss Alps (PERMOS 2009). However, anomalous years such as

49 the exceptional hot summer 2003 in the European Alps can lead to strong increases of the active

50 layer thickness (HILBICH et al., 2008).

51 With permafrost influencing the ground stability, a thicker active layer could increase the risk

52 potential for rockfalls, landslides or debris flow (HARRIS et al., 2009). For example, a higher

53 number of observed rockfall events in 2003 has been attributed to be the consequence of the

54 increased active layer thickness due to the extremely high summer temperatures (GRUBER et al.,

55 2004). Hence, in mountainous and highly populated and touristic regions like the European Alps,

56 a profound knowledge of the permafrost distribution and its future evolution is of high impor-

57 tance.

${ }_{58}$ Mountain permafrost in the European Alps has been studied since the 1970s, and in a recent re-

59 view paper HARRIS et al. (2009) have summed up current monitoring and modelling approaches

60 to analyse the response of mountain permafrost to climate trends in Europe. One of the ap-

61 proaches is based on temperature measurements in deep $(100 \mathrm{~m})$ boreholes, such as within the

62 European PACE project (Permafrost and Climate in Europe, HARRIS et al. (2001)) as part of

63 the Global Terrestrial Network Permafrost (GTN-P) within the Global Climate Observing Sys-

64 tem (GCOS, BURGESS et al. (2000)). In addition, the Swiss permafrost monitoring network 
PERMOS currently includes more than 15 permafrost monitoring stations measuring ground temperature, meteorological variables, subsurface properties like the electrical resistivity which 67 can be related to ice content and slope movements (VONDER MÜHLL et al. (2007); PERMOS 68 2009). Due to the fact that the number of boreholes and monitoring stations is far from sufficient to cover all areas in the Alps where permafrost is present, and in order to analyse the future evo71 lution of the thermal state and the ground ice content of these occurrences, subsurface model approaches of different complexity are usually performed (for reviews see RISEBOROUGH et al.

73 (2008); HARRIS et al. (2009)). In the Alps, the heterogeneity of the surface and subsurface as 74 well as topography complicates long-term modelling. One of the potentially most important subsurface variables is the soil water content, which influ76 ences both thermal and hydraulic processes within the subsurface. Soil moisture measurements 77 in high alpine permafrost terrain are very scarce and often difficult to conduct (see e.g. RIST and PHILliPS (2005)). Besides direct measurements, indirect methods such as Electrical Resistivity

79 Tomography can be used to determine the water content of the subsurface for modelling pur80 poses (SCHERLER et al., 2010). At mountain permafrost sites, soil moisture and its variability

81 is usually extremely low during winter, with an abrupt increase when infiltration processes from 82 the melting snow cover start. Afterwards, soil moisture values increase continuously but slowly 83 until a high-variability pattern indicates the direct influence of the atmosphere and therefore a

84 complete absence of an isolating snow cover (HILBICH and HAUCK, 2010).

85 Apart from uncertainties regarding the subsurface composition, a simple downscaling of Re86 gional Climate Model (RCM) simulation data as forcing data set for subsurface permafrost mod-

87 els is not possible, because small-scale variability of topographic effects are a major problem for ${ }_{88}$ precipitation modelling in the Alps (FREI et al. (2003); SALZMANN et al. (2007c)). This influ89 ences especially the model results for the snow cover evolution, which is one of the major param- 
eters for permafrost evolution. LÜTSCHG et al. (2008) simulated the influence of the snow cover

91 on the ground temperature regime by the use of the one-dimensional model SNOWPACK and

92 found a larger sensitivity of the ground thermal regime to changes in snow cover than to changes

93 in the mean annual air temperature. This complex spatial and temporal reaction pattern of per-

94 mafrost to atmospheric forcing parameters (due to the isolation effect of the temporally limited

95 presence of the snow cover) prevents a simple coupled and/or dynamically downscaled impact

96 modelling of climate induced changes of the permafrost regime (SALZMANN et al., 2007b).

97 As a first step to the modelling of the future evolution of mountain permafrost, we want to present

98 idealised simulations using a complex subsurface model to analyse the sensitivity of mountain

99 permafrost to different atmospheric forcing parameters, namely air temperature and precipitation. The paper is structured as follows: Section 2 shortly introduces the field site Schilthorn,

101 which was used for validation of the model results. The one-dimensional subsurface model 102 (CoupModel), which was used for the permafrost simulations of this study, as well as the RCM forcing data sets that were used for the long-term simulations are described in section 3. Section

1044 shows the validation of the model by comparing observed and modelled ground temperatures during the control period as well as simulations of the sensitivity to various idealised forcing

106 scenarios and RCM data sets. Finally, conclusions are presented in section 5.

\section{${ }_{107} 2$ Field site}

108 One of the field sites within the Swiss permafrost monitoring network (PERMOS) project is the 109 Schilthorn (2970 m asl), Berner Oberland, Northern Swiss Alps. Since the first investigation 110 by IMHOF (1996), extensive permafrost research has taken place on Schilthorn (e.g. HAUCK 111 (2002); Hilbich et al. (2008); Imhof et al. (2000); Mittaz et al. (2002); NoetZli et al. 112 (2008); VONDER MÜHLl et al. (2000)), making it one of the most intensively investigated ${ }_{113}$ permafrost sites in the European Alps. In 1998 the first of three boreholes (14 m deep, followed 
114 by two $100 \mathrm{~m}$ deep boreholes in 2000) has been drilled on its northern flank at $2900 \mathrm{~m}$ asl. A

115 meteorological station and a permanently installed electrical resistivity tomograph (ERT) profile

116 to study subsurface freeze and thaw processes provide additional data since 1999 (HAUCK et al.,

117 2005).

118 Based on the above data sets, subsurface modelling studies using the coupled heat and mass

119 transfer model COUP (see section 3.1) were initiated to simulate freeze and thaw processes at

120 Schilthorn on different scales. VÖLKSCH (2004) found significant differences in the permafrost

121 reaction in two boreholes situated only $15 \mathrm{~m}$ apart from each other and attributed these to

122 differences in the surface characteristics, including snow cover variability. SCHERLER et al.

${ }_{123}$ (2010) successfully simulated the heat and mass transport processes in the active layer during

124 the snow melt period in early summer to analyse the reaction of the meltwater infiltration on the

125 ground temperature regime. However, no simulations on longer time scales have been performed

126 So far.

\section{${ }_{127} 3$ Methods}

\subsection{Numerical model}

In this study we use the CoupModel (Coupled heat and mass transfer model for soil-plantatmosphere systems) for modelling the evolution of the active layer thickness and its sensitivity to atmospheric forcing parameters. The one-dimensional model consists of different sub-modules, which have been integrated into a system of models (JANSSON and KARLBERG, 2001). The model includes water and heat processes in any soil independent of plant cover. It has been extended by (STÄHLI et al., 1996) by a frost module to cover freezing and thawing processes. Radiation, wind speed, moisture, air temperature and precipitation data are the basic driving variables of the model. Precipitation data can be directly used as forcing variables or can be generated by the model. In the latter case the frequency and the amount of precipitation can be 
138

prescribed, which was used to generate the input data for the idealised simulations (see below).

The snow cover in the model is simulated in a horizontally and vertically homogeneous layer (divided into old snow and new snow) with variable thickness and is generated by a specific snowpack module.

Energy and mass balances are calculated along a vertical profile using finite differences, so the soil can be divided into a finite number of layers. For our calculations we use a total of 75 layers and one layer for the snow cover. Calculations are performed for each of these layers. For all layers the most important ground parameters have to be provided, i.e. the porosity, the water content, the tortuosity, the heat capacity and the thermal conductivity of the ground.

The model has already been used successfully for mountain permafrost investigations by VÖLKSCH (2004) and SCHERLER et al. (2010). In addition, the performance of the snow module was successfully compared within the Snow Model Intercomparison Project (SnowMIP) (ETCHEVERS et al. (2004); ESSERY et al. (2009)).

Radiation and air temperature from the energy balance station at the Schilthorn borehole site were used as forcing data sets for our simulations. A model spin-up of 24 years was performed to generate a stable and consistent initial model for the long-term simulations of the uppermost $10 \mathrm{~m}$. Validation of the thermal conditions after the model spin-up and subsequent model simulations were conducted using ground temperature measurements within the boreholes at Schilthorn.

\subsection{RCM data}

57 Forcing data sets for long-term sensitivity analyses were taken from an ensemble of Regional 58 Climate Model (RCM) simulations which were already used for impact modelling of the evolution of ground surface temperatures and rock surface temperature (SALZMANN et al. (2007c); SALZMANN et al. (2007a); NoETZLi et al. (2008)). In the present study we now go one step further and use these forcing data sets to analyse the sensitivity of subsurface temperatures 
162

and active layer thickness at a mountain permafrost site.

The RCM-based daily scenario time series were derived from the results of five RCM simulations performed within the European project PRUDENCE (CHRISTENSEN et al., 2002). 10 scenario time series (2071-2093) were derived from the following three RCMs: (1) CHRM (Climate High Resolution Model) (e.g. LÜTHI et al. (1996); VIDALE et al. (2003)), (2) RegCM (Regional Climate Model) (e.g. Giorgi and Mearns (1999); PAL et al. (2000)), and (3) HIRHAM (regional atmospheric climate model) (e.g. CHRISTENSEN et al. (1996)). Each of these RCMs was driven by the HadAM3H Global Climate Model from the Hadley Centre, forced by the SRES emission scenarios A2 and B2 (CHRM only by A2). Outputs from the RCMs were adjusted for high mountain impact analyses using the delta and bias approaches, discussed in detail by SALZMANN et al. (2007c). Using the delta approach the difference between the monthly mean values of the scenario run $\left(s c e n_{\text {mean }}\right)$ and the control run $\left(c t r l_{\text {mean }}\right)$ are added to the daily observation data $(o b s)$ of the control period (Equation 3.1). The bias approach subtracts the difference between the monthly mean values of the control run $\left(c t r l_{\text {mean }}\right)$ and the daily observation data $\left(o b s_{\text {mean }}\right)$ from the scenario time series (scen) (Equation 3.2).

$$
\operatorname{scen}_{\text {Delta }}=\text { obs }+\left(\text { scen }_{\text {mean }}-c t r l_{\text {mean }}\right)
$$

$$
\text { scen }_{\text {Bias }}=\text { scen }-\left(\text { ctrl } l_{\text {mean }}-o b s_{\text {mean }}\right)
$$

B8 Both approaches use output from the RCM grid box whose monthly control run data statistically fit best with the respective time series of the meteorological station next to it, namely the station Corvatsch, Upper Engadine for the data set of SALZMANN et al. (2007a,b). The advantage of the delta approach is that regional distinctions (e.g. extremes) are kept within the data set, whereas the bias approach produces time series whose variability of temperature at the given grid box may not be representative for the location of the observations. The disadvantage of the delta approach is that it ignores possible changes in variability of the respective parameter, whereas 
185

the bias approach retains the variability from the RCM simulation (SALZMANN et al., 2007c). In this study, bias and delta modified temperature and precipitation values were included in the scenario time series.

\section{Results}

\subsection{Validation of the model}

Within this section, the performance of the CoupModel for the mounatin permafrost field site is validated using snow depth, subsurface temperature at different depths and the mean active layer thickness during the control period (1999-2007). First, precipitation during the control period has been derived by the model using measured snow depths and air temperature. Hereby, settling and melting of the snow cover is taken into account within the snow module of the CoupModel, where settling of the snow cover depends on the free water content in the snow cover, overburden pressure and age of the snow cover. Second, the ground parameters in the model have been adjusted to simulate the correct ground temperatures according to the measurements.

Comparing the snow depth of the model output with the observations (Figure 1) the ability of the model to reproduce the timing and duration of the snow cover becomes apparent, which is important for the permafrost evolution. Observed maximal snow depths and the variability are larger than in the modelled data, but especially the start and the end of the period of significant snow cover are rather similar. Consequently, the model reproduces the observations quite well in the period where the ground is free of snow or covered with little snow. For the period when the snow cover is thick enough to isolate the ground from atmospheric forcing the accuracy of modelled snow depths is less important, as modelled subsurface temperatures will not be affected. As a substantially thick snow cover effectively isolates the ground from atmospheric processes, errors in the simulated duration of the snow cover will have a larger impact on ground temperature than differences between observed and modelled absolute snow depths. 
The observed temperatures at $5 \mathrm{~m}$ depth in both boreholes are below zero in most years (Figure 2). While the minimum temperature varies around $-1{ }^{\circ} \mathrm{C}$ the maximum temperature during the summer stays almost constantly close to the freezing point corresponding well to a mean active layer depth of $4.8 \mathrm{~m}$ at Schilthorn (PERMOS 2009). An exception can be seen in 2003, where maximal temperatures were positive with values up to $0.7^{\circ} \mathrm{C}$ and $1.3{ }^{\circ} \mathrm{C}$ in the two

boreholes, respectively. This positive anomaly is due to the extremely hot summer in 2003 in Europe and also in the European Alps, with an increase in the occurrence of slope instability events and ice melt at mountain permafrost sites (GRUBER et al. (2004); HILBICH et al. (2008)). As can be seen from Figure 2, the CoupModel reproduced the temperature variations at this depth very well. The differences to the observed data are small $\left(<0.2{ }^{\circ} \mathrm{C}\right)$ and within the range of the temperature difference of the two boreholes which are situated only $15 \mathrm{~m}$ apart from each other (PERMOS 2009). Figure 3 shows the results from the modelled and observed active layer depths for the same time period. The increase in active layer depth from about $5 \mathrm{~m}$ to $9 \mathrm{~m}$ was extreme and larger than at the other permanent monitoring sites within PERMOS (PERMOS 2009). Again, simulations and observations agree well with a slight underestimation of the 2003 anomaly in the model results.

\subsection{Idealised modelling}

To analyse the seasonally variable importance of the dominant forcing variables and their respective impact on ground temperatures and active layer depth, we performed a sensitivity study using reduced and increased precipitation and air temperature values. One of the dominant forcing parameter of mountain permafrost is the duration of the snow cover. Using the average temperature and from the temperature and the snow depth derived average precipitation sum of every day between 1999 and 2007, the CoupModel produces a snow free period between mid-July and the end of September (Figure 4). Increasing (decreasing) the mean annual air 
temperature (MAAT) by $1 \mathrm{~K}$ leads to an earlier (delayed) begin of the snow free period of 2 weeks. A reduction (increase) of the annual precipitation sum by $30 \%$ influences the start of the snow free period to the same amount.

The beginning of a permanent snow cover in autumn is similarly influenced by air temperature and precipitation. However, due to the dependence of snow fall on both, temperature and precipitation, the beginning of a snow cover with significant thermal isolation characteristics in autumn is not as clearly defined as the end of the snow cover in early summer. A rise of the MAAT by $1 \mathrm{~K}$ leads to a delay of a minimum snow cover of $20 \mathrm{~cm}$ of almost 3 weeks. With a temperature decrease of the same amount the snow cover reaches this threshold value almost 2 weeks earlier. With a rise or a reduction of the annual precipitation sum of $30 \%$ the threshold of a snow depth of $20 \mathrm{~cm}$ varies also in the range of 1 month between the beginning of October and the beginning of November.

Due to the strong dependence of ground temperatures on the timing and duration of the snow cover, the sensitivity of mountain permafrost will depend not only on the changes of mean parameters (such as MAAT, see LÜTSCHG et al. (2008)), but also on seasonal or monthly temperature and precipitation anomalies. To analyse this sensitivity the simulations of Figure 4 were repeated, but now with monthly instead of annual anomalies. The resulting active layer depth was determined for the monthly sensitivity experiments. The differences to the active layer depth of the control run $(4.4 \mathrm{~m})$ are shown in Figure 5. Monthly mean temperatures are changed by $\pm 3 \mathrm{~K}$ and precipitation sums were doubled/set to zero, the latter simulating the extreme case of dry conditions during a whole month.

As seen in Figure 5a and b, air temperature changes between November and April have minor effects on the active layer thickness as the snow cover decouples the ground thermal regime from atmosphere. Between May and September a change of the monthly mean temperature of $3 \mathrm{~K}$ leads to a change of the active layer thickness in the same year between $60 \mathrm{~cm}$ and $100 \mathrm{~cm}$ with 
maximum values between June and August. During these months the temperature anomalies have an almost linear effect on the active layer thickness with approximately $30 \mathrm{~cm}$ per degree temperature change (Figure 6). This is a similar result as found by LÜTSCHG et al. (2008)

who reported a linear relationship between the MAAT and the mean annual ground surface temperature, whereas we found a linear relationship between the air temperature during the summer months and the active layer thickness.

Regarding monthly precipitation anomalies, a dry month between December and May reduces the snow depth at the beginning of the thawing period. This results in a slightly reduced snow cover duration and a corresponding increase of the active layer by about $20 \mathrm{~cm}$ to $40 \mathrm{~cm}$ (Figure 5d). On the contrary, dry months between June and August have minor effects on the active layer thickness. A dry month during autumn has a negative effect on the active layer thickness, because the ground surface stays longer without or with only little snow. Without the isolating effect of the snow outgoing long-wave radiation leads to a more rapid cooling of the soil and the active layer in the following year is less deep. A doubling of the monthly precipitation sum (Figure 5c) has generally the opposite effect on the active layer thickness than a lack of precipitation. An important exception can be found in autumn, where both, an increase and a reduction of the precipitation lead to a reduction of the active layer. With the precipitation falling as snow often already in mid-September, the snow depth at the end of the winter is also dependent on the precipitation in these months. An increase in precipitation in autumn can lead to a higher total snow cover in early summer, thus prolonging its isolating effect against summer insolation and decreasing the active layer thickness. Even though less precipitation yields reduced snow depths and earlier snow melt in spring, the lack of isolation in autumn seems to be more significant. Figure 7 shows this non-linear effect of the precipitation sum in October regarding the active layer thickness in the following year. For monthly precipitation sums larger than used in the control run, the active layer thickness decreases, but with decreasing slope. 
283

For decreasing precipitation, the active layer thickness reaches its maximum at around $50 \%$ of the average precipitation sum in October (control run), however, with a further reduction of precipitation the lack of the isolating effect of the snow during cold days becomes more important and results in a reduced active layer thickness.

To analyse the combined effect of temperature and precipitation changes simulations with coupled temperature and precipitation anomalies were conducted. The results show that the influence of temperature and precipitation changes cannot simply be added (Table 1). Between November and April, the temperatures are below $0{ }^{\circ} \mathrm{C}$ even during warm weather periods, therefore, the degree of influence on the ground thermal regime is driven by precipitation. Between May and October, however, precipitation is falling as snow or rain, depending on the temperature. If these months are warmer than average, the influence of precipitation anomalies on the active layer thickness is minor, as rain has a correspondingly minor impact on the ground thermal regime. On the other hand, precipitation during anomalously cold months is falling as snow, even during summer. Consequently, the ground receives more snow in cold and wet spring and summer months which has to be melted before a warming may take place in the ground. Cold and completely dry months, which have a sufficiently thick snow cover such as May, will not significantly influence the ground thermal regime, whereas bare ground in a cold month (e.g. August or October) leads to rapid ground cooling and to a reduction of the active layer thickness similar to cold and wet months (Table 1).

\subsection{Simulations with RCM ensemble time series}

In order to study the sensitivity of the active layer thickness to potential long-term changes of atmospheric forcing data an ensemble of $11 \mathrm{RCM}$-generated time series of air temperature have been used as input data for the CoupModel. Hereby, the properties of the soil model were left unchanged with respect to the results shown in the previous chapter. 10 of these data 
sets comprise combinations of three different regional climate models, two different emission scenarios (A 2 and B 2) and the two transfer approaches (delta and bias) for the period 20712093. Additionally, one data set was generated from observations for the period 1981-2003 for a permafrost monitoring station in the Corvatsch/Murtèl area, Upper Engadine (SALZMANN et al., 2007c).

The result for the control run (obs) with the CoupModel using the observation data as forcing gives an active layer thickness of $3.0 \mathrm{~m}$. This corresponds quite well with the observed mean active layer thickness at the Corvatsch field site of 3.4 m between 1987-2003 (VONDER MüHLL et al., 2007). Using the data sets for the end of the 21 st century, the CoupModel simulates a massive rise of the mean active layer thickness to $6 \mathrm{~m}$ to $14 \mathrm{~m}$ (Figure 8). Except for the simulation results of the CHRM, models using data sets with the delta approach produce less deep modelled mean active layer thicknesses compared with the values of the data sets which use the bias approach. This indicates that changes in variability of temperature or precipitation have an additional effect on the rise of the mean active layer thickness. In the simulations with an average active layer thickness of more than $10 \mathrm{~m}$, the ground remains partly unfrozen during some winters, leading to the onset of permafrost degradation and talik formation.

As seen from Figure 8, differences between the results of the individual ensemble members can be very large even if the same scenario and transfer approaches are used. For example, the two RCM input data sets a2bc and a2bh for temperature and precipitation differ only in the used Regional Climate Model (a2bc: CHRM, a2bh: HIRHAM) but lead to an increase of the mean active layer thickness of $6.8 \mathrm{~m}$ and $13.8 \mathrm{~m}$, respectively. The annual mean values for air temperature and precipitation in the two RCM data sets differ only little from each other (Table 2). However, a significant distinction can be found in the partitioning of the precipitation amount to rain and snow in the month of October. In this month, more precipitation falls with mean temperatures $>0{ }^{\circ} \mathrm{C}$ in the a2bh data set than with negative temperatures. This 
corresponds well with a positive monthly mean temperature of $+1.2{ }^{\circ} \mathrm{C}$. In the a2bc data set, there is about twice as much precipitation on days with a positive mean temperature than on days with temperatures below the freezing point, although the monthly mean temperature is near $0{ }^{\circ} \mathrm{C}$ and therefore smaller than for a2bc. Consequently, in the CHRM precipitation in October is more likely to fall as rain leading to a tendency of cold days with little or no snow in autumn, whereas an early snow cover is more likely to appear in the HIRHAM simulations. This could indicate that CHRM simulates slightly different general weather conditions than HIRHAM. As described in detail by LAWRENCE and SLATER (2009), cold days in autumn with no or only a slight snow cover lead to a cooling of the subsurface and consequently to a smaller increase of the mean active layer thickness. This effect can be observed for the simulation results of the CHRM data set (Figure 8).

\section{Conclusions}

The CoupModel, a coupled heat and mass transfer model, was adapted to the characteristics and observed ground temperatures in the summit area of the Schilthorn field site, a permafrost region in the Northern Swiss Alps. Validation experiments for the period 1999-2007 show a good agreement between simulated subsurface temperatures with data from borehole measurements at different depths.

Since the isolating effect of the snow cover is able to significantly reduce both the warming of the subsurface and its cooling, the onset and the end of snow cover plays a major role in all model simulations. As accurate simulations of the future evolution of precipitation and snow cover are difficult to obtain on a local scale in alpine regions, idealised model simulations were conducted to analyse the sensitivity of the mountain permafrost regime to these atmospheric forcing parameters. The model simulations revealed the influence of monthly and seasonal anomalies of temperature and precipitation on the active layer thickness. In summer, temperature changes 
have the largest impact on the ground thermal regime, as the absence of the snow cover directly couples the atmospheric evolution to the ground. In August, the month with the potentially largest impact of air temperature changes, an increase/decrease of the monthly mean temperature of $1 \mathrm{~K}$ leads to a change in the active layer thickness on the order of $30 \mathrm{~cm}$. On the contrary, the simulations showed that summer precipitation has a minor impact on the active layer evolution. Winter precipitation has a direct effect on the total height of the snow cover in spring and therefore on the onset of the snow melt in early summer. Increased (decreased) winter precipitation leads therefore to a decrease (increase) of the active layer thickness in the next year. An important non-linear effect can be observed for temperature and precipitation in autumn. Due to the fact that air temperatures in autumn can be positive as well as negative, they determine whether autumn precipitation falls as rain or snow, the latter being necessary for the evolution of a persistent and isolating snow cover. Sensitivity analyses with increased and decreased precipitation amounts showed that the characteristics of the temperature and precipitation regimes in October may lead to both, significant increase and decrease of the active layer thickness in the following year. However, for the idealised settings of our model study, a tendency for an active layer thickness decrease due to changing precipitation forcing in October could be observed. Sensitivity studies using an ensemble of RCM-derived forcing data sets for the period 2071-2093 give insights into a possible range of climatic impacts on the permanently frozen subsurface and the dependencies of subsurface temperatures on changing air temperature and precipitation characteristics. For all scenarios the CoupModel simulates a prominent increase of the mean active layer thickness with beginning permafrost degradation and talik formation for some of the ensemble scenarios. The major cause of this is the increase of mean summer temperatures in all RCM scenario simulations. Besides, the amount and the time of the first snow event in autumn control the active layer thickness in the following year. In addition to the evolution of summer air temperatures, a dominant forcing parameter for the evolution of mountain permafrost is therefore 
381 the future partitioning of the precipitation amount in rain and snow in autumn.

We believe that further sensitivity studies using complex one-dimensional subsurface models

383 such as the CoupModel will help to clarify the future, non-linear response of mountain per-

384 mafrost to climate change scenarios.

\section{${ }_{385}$ Acknowledgments}

${ }_{386}$ The work was done within the project "Sensitivity of Mountain Permafrost to Climate Change

${ }_{387}$ (SPCC)" (DFG HA 3475/3-1). We thank two anonymous reviewer who helped to improve the 388 paper.

\section{звя References}

Burgess, M. M., S. L. Smith, J. Brown, V. Romanovsky, K. Hinkel, 2000: Global Terrestrial Network for Permafrost (GTN-P): permafrost monitoring contributing to global climate observations. - Geological Survey of Canada, Current Research 2000-E14.

Christensen, J. H., O. B. Christensen, P. Lopez, E. V. Meijgahrd, M. Botzet, 1996: The HIRHAM4 regional atmospheric climate model. - Sci. Rep. 96, 51 pp., Dan. Meteorol. Inst., Copenhagen.

Christensen, J. H., T. R. CARTer, F. Giorgi, 2002: PRUDENCE employs new methods to assess European climate change. - Eos Trans. AGU 83(147).

Essery, R., N. Rutter, J. Pomeroy, R. BAXter, M. Stähli, D. Gustafsson, A. Barr, P. BARTlett, K. Elder, 2009: SNOWMIP2: An Evaluation of Forest Snow Process Simulations. - Bulletin of the American Meteorological Society 2009 90, 1120-1135. 
Etchevers, P., E. Martin, R. Brown, C. Fierz, Y. Lejeune, E. Bazile, A. Boone, Y.J. Dai, andA. R. E. Fernandez, Y. Gusev, R. Jordan, V. Koren, E. Kowalczyk, N. O. Nasonova, R. D. Pyles, A. Schlosser, A. B. Shmakin, T. G. Smirnova, U. Strasser, D. Verseghy, T. YAMAZAKI, Z.-L. YAng, 2004: Validation of the surface energy budget simulated by several snow models (snowmip project). - Ann. Glaciol. 38, 150158.

Frei, C., J. H. Christensen, M. Deque, D. Jacob, R. G. Jones, P. L. Vidale, 2003: Daily precipitation statistics in Regional Climate Models: evaluation and intercomparison for the European Alps. - J. Geophys. Res. D3, 4124 pp., doi:10.1029/2002JD002287.

French, M. M., 1996: The Periglacial Environment - 2nd edn. Addison Wesley, London.

Giorgi, F., L. O. MEARNS, 1999: Introduction to a special section: Regional climate modeling revisited. - J. Geophys. Res. 104, 6335-6352.

Gruber, S., M. Hoelzle, W. Haeberli, 2004: Permafrost thaw and destabilization of Alpine rock walls in the hot summer of 2003. - J. Geophys. Res. 31, L13504, doi:10.1029/2004GL020051.

Harris, C., W. Harberli, D. Vonder Mühll, L. King, 2001: Permafrost monitoring in the high mountains of europe: the pace project in its global context. - Permafrost Periglac. Process. 12(1), 3-11, doi:10.1002/ppp.377.

Harris, C., L. U. Arenson, H. H. Christiansen, B. Etzelmüller, R. Frauenfelder, S. Gruber, C. H. W. Haeberli, M. Hoelzle, O. Humlum, K. Isaksen, A. Kä̈̈B, M. L. M. A. Kern-Lütschg, N. Matsuoka, J. B. Murton, J. Noetzli, M. Phillips, N. Ross, S. M. S. M. Seppëlä, D. Vonder Mühll, 2009: Permafrost and climate in Europe: Monitoring and modelling thermal, geomorphological and geotechnical responses. Earth-Science Reviews 92, 117-171, doi:10.1016/j.earscirev.2008.12.002. 
HAUCK, C., 2002: Frozen ground monitoring using dc resistivity tomography. - Geophysical Research Letters 29(21), 2016, doi:10.1029/2002GL014995.

Hauck, C., D. Vonder Mühll, M. Hoelzle, 2005: Permafrost monitoring in high mountain areas using a coupled geophysical and meteorological approach. - Climate and Hydrology of Mountain Areas, eds: C. de Jong, D. Collins, R. Ranzi, Wiley 59-71.

Hilbich, C., C. HAUCK, 2010: Automated time-lapse ERT for improved process analysis and long-term monitoring of frozen ground. - Permafrost and Periglac. Process. , in review.

Hilbich, C., C. Hauck, M. Hoelzle, M. Scherler, L. Schudel, I. VölKsch, D. VonDER MÜHLL, R. MÄUSEBACHER, 2008: Monitoring mountain permafrost evolution using electrical resistivity: A 7-year study of seasonal, annual, and long-term variations at Schilthorn, Swiss Alps. - J. Geophys. Res. 113, doi:10.1029/2007JF000799.

IMHOF, M., 1996: Modelling and Verification of the Permafrost Distribution in the Bernese Alps (Western Switzerland). - Permafrost Periglac. Process 7, 267-280.

Imhof, M., G. Pierrehumbert, W. Haeberli, H. Kienholz, 2000: Permafrost Investigation in the Schilthorn Massif, Bernese Alps, Switzerland. - Permafrost Periglac. Process 11, 189 pp.

Jansson, P. E., L. Karlberg, 2001: Coupled Heat and Mass Transfer Model for SoilPlant-Atmosphere Systems. - Royal Institute of Technology. - Department of Civil and Environmental Engineering, Stockholm

Lawrence, D. M., A. G. Slater, 2009: The contribution of snow trends to future ground climate. - Clim. Dyn., doi:10.1007/s00382-009-0537-4.

LÜthi, D., A. CRESS, C. FREI, C. SCHÄR, 1996: Interannual variability and regional simulations. - Theor. Appl. Climatol. 53, 185-209. 
LÜTSChG, M., M. Lehning, W. HAEberLI, 2008: A sensitivity study of factors influencing warm/thin permafrost in the Swiss Alps. - J. of Glaciology 54, 696 pp.

Mittaz, C., M. Imhof, M. Hoelzle, W. Haeberli, 2002: Snowmelt evolution mapping using an energy balance approach over an alpine terrain. - Arctic, Antarctic and Alpine Research 34(3), 274-281.

Noetzli, J., S. Gruber, C. Hilbich, M. Hoelzle, C. Hauck, M. Krauer, 2008: Comparison of Simulated 2D Temperature Profiles with Time-Lapse Electrical Resistivity Data at the Schilthorn Crest, Switzerland. - Proceedings of the 9th International Conference on Permafrost 2008, Fairbanks 1293-1298.

Pal, J. S., E. E. Small, E. A. B. Eltahir, 2000: Simulation of regionalscale water and energy budgets: Representation of subgrid cloud and precipitation processes within RegCM. - J. Geophys. Res. 105, 29,579-29,594.

PeRmos 2009: J. Noetzli, B. NAegeli, D. Vonder MÜhll (eds.), 2009: Permafrost in Switzerland 2004/2005 and 2005/2006. - Glaciological Report Permafrost No. 6/7 of the Cryospheric Commission of the Swiss Academy of Sciences 100 pp.

Riseborough, D., N. I. Shiklamonov, B. Etzelmüller, S. Gruber, S. Marchenko, 2008: Recent advances in permafrost modeling. - Permafrost and Periglac. Process. 19(2), $137-156$.

Rist, A., M. PhILliPS, 2005: First results of investigations on hydrothermal processes within the active layer above alpine permafrost in steep terrain. - Norwegian Journal of Geography 59(2), 177-183. 
Salzmann, N., J. Noetzli, C. Hauck, S. Gruber, M. Hoelzle, W. Haeberli, 2007a: Ground surface temperature scenarios in complex high-mountain topography based on regional climate model results. - J. Geophys. Res. 112, F02S12, doi:10.1029/2006JF000527.

Salzmann, N., S. Gruber, M. Hugentobler, M. Hoelzle, 2007b: Influence of different digital terrain models (DTMs) on alpine permafrost modeling. - Environ. Model Assess. 12, 303 pp., doi:10.1007/s10666-006-9065-3.

Salzmann, N., C. Frei, P.-L. Vidale, M. Hoelzle, 2007c: The application of Regional Climate Model outputs for the simulation of high-mountain permafrost scenarios. - Global and Planetary Change 56, 188 pp., doi:10.1016/j.gloplacha.2006.07.006.

Scherler, M., C. Hauck, M. Hoelzle, M. Stähli, I. VölKsch, 2010: Meltwater infiltration into the frozen active layer at an alpine permafrost site. - Permafrost Periglac. Process. , in press.

Stähli, M., , P.-E. Jansson, L. C. Lundin, 1996: Preferential flow in a frozen soil - a two-domain model approach. - Hyd. Proc. 10, 1305-1316.

Vidale, P. L., D. Lüthi, C. Frei, S. I. Seneviratne, C. Schär, 2003: Predictability and uncertainty in a regional climate model. - J. Geophys. Res. 108(D18), 4586.

VÖLKSCH, I., 2004: Untersuchung und Modellierung kleinräumiger Unterschiede im Verhalten von Gebirgspermafrost. Diplomarbeit, Department Erdwissenschaften, Eidgenössische Technische Hochschule Zürich.

Vonder MüHll, D., C. Hauck, F. Lehmann, 2000: Verification of geophysical models in Alpine permafrost using borehole information. - Annals of Glaciology 31, 300-306. 
Vonder Mühll, D., J. Noetzli, I. Roer, K. Makowski, R. Delaloye, 2007: Permafrost in Switzerland 2002/2003 and 2003/2004. - Glaciological Report (Permafrost) No. 4/5 106 pp., Cryospheric Commission (CC) of the Swiss Academy of Natural Sciences (SCNAT) and Department for Geography, University of Zurich.

494 Williams, P. J., M. W. SMith, 1989: The Frozen Earth: Fundamentals of Geocryology. Cambridge University Press, Cambridge. 


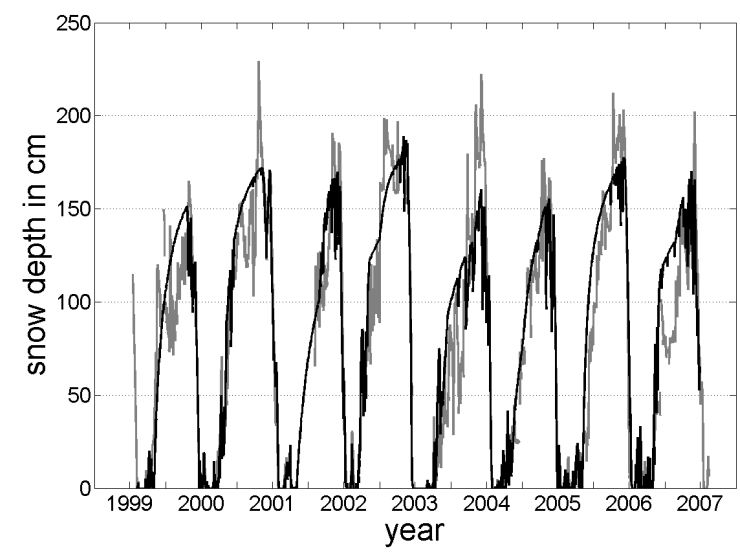

Figure 1: Snow depth from model output (black) and from measurements (grey).

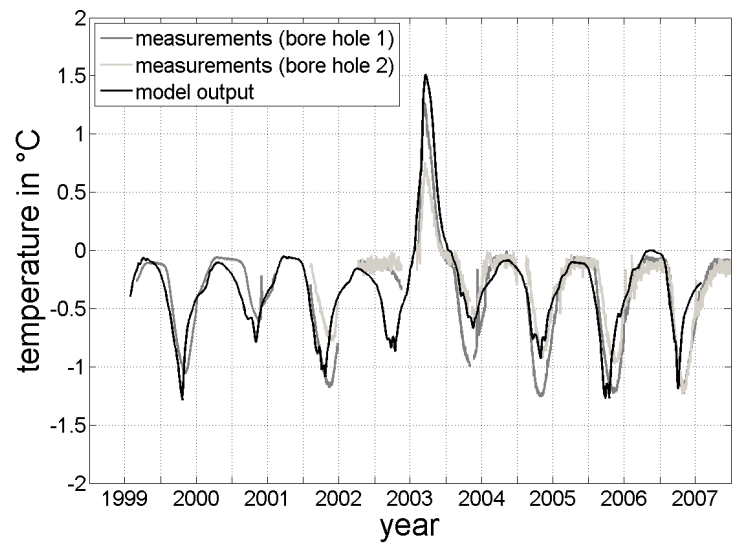

Figure 2: Ground temperature in a depth of $5 \mathrm{~m}$ from model output and from measurements of two boreholes.

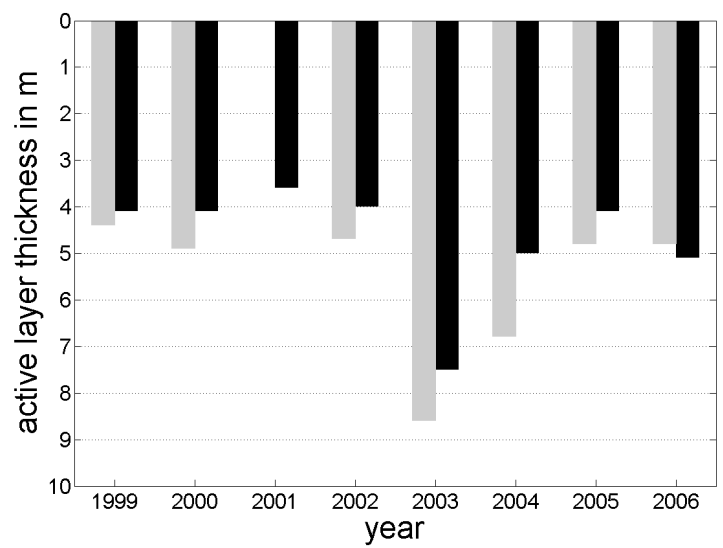

Figure 3: Active layer thickness from measurements (grey) (see HILBICH et al. (2008)) and from CoupModel (black) (there are no measurements for 2001). 


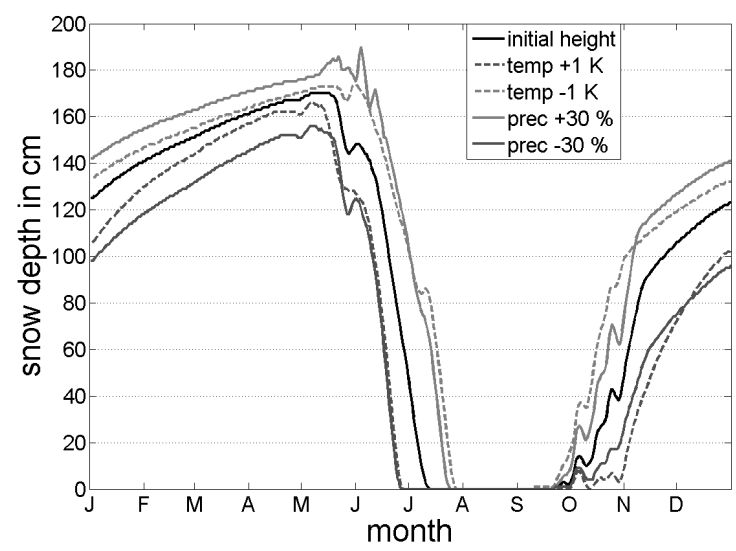

Figure 4: Change of the modelled snow depth with changes of the temperature by 1 Kelvin and the precipitation by $30 \%$.
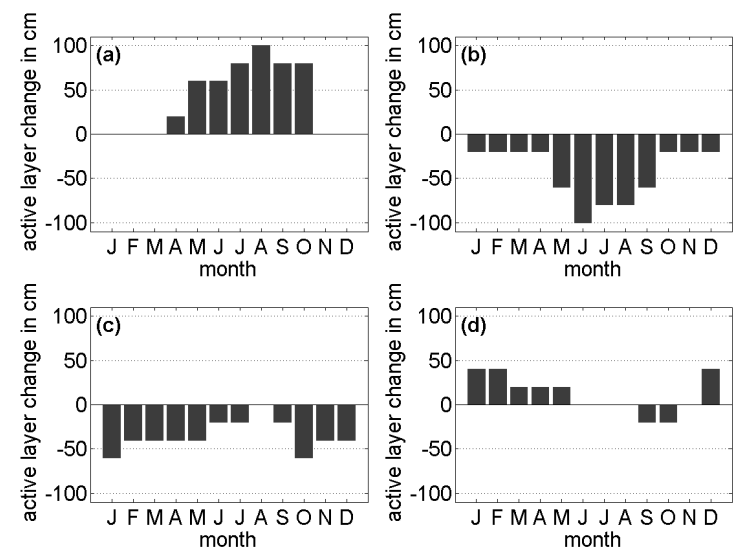

Figure 5: Overview of the changes in active layer depth to the control run $(4.4 \mathrm{~m})$ with unique selected modified parameters in each month. a) temperature $+3 \mathrm{~K}, \mathrm{~b}$ ) temperature $-3 \mathrm{~K}$, c) double precipitation, d) no precipitation. 


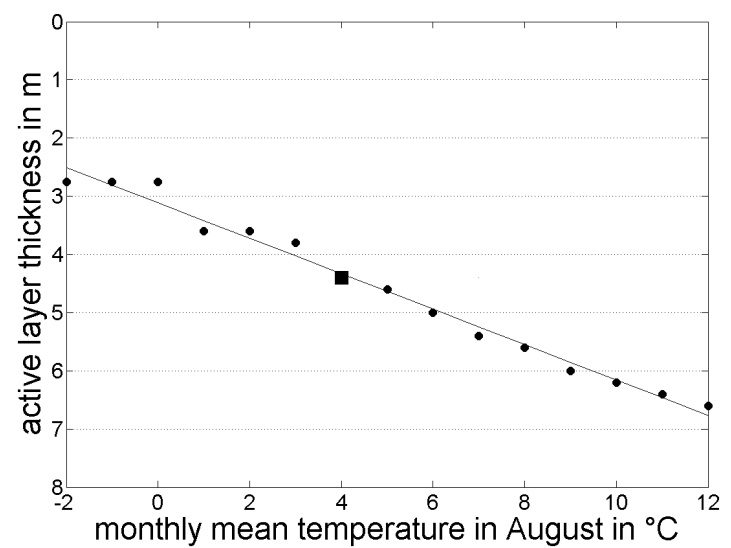

Figure 6: Influence of air temperature in August on the active layer thickness; the control run with no changes is indicated by the square.

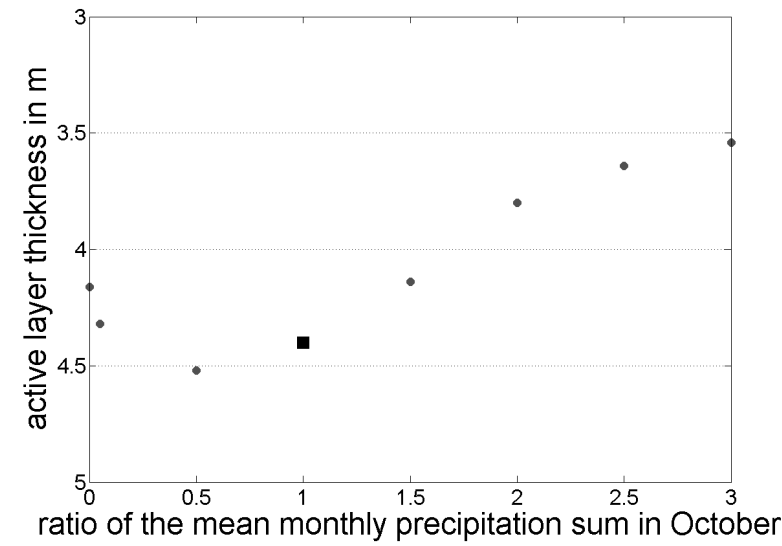

Figure 7: Influence of precipitation in October on the active layer thickness; the control run with no changes is indicated by the square. 


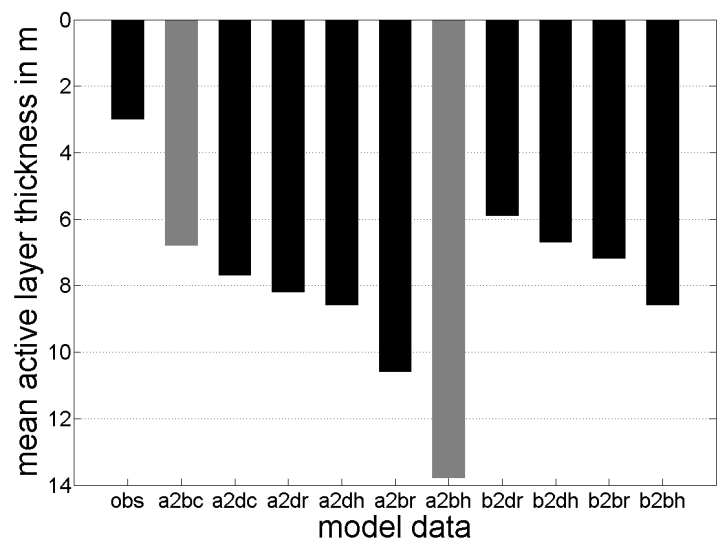

Figure 8: Modelled mean active layer thickness for the control run (1981-2003) and for 10 RCM ensemble data for 20712093, whereas the first two characters indicate the emission scenario (a2 and b2), the third indicates the used downscaling approach ( $\mathrm{b}=$ bias or $\mathrm{d}=$ delta) and the last the used climate model ( $\mathrm{c}=\mathrm{CHRM}, \mathrm{r}=$ RegCM and $\mathrm{h}=$ HIRHAM); the markedly different model data shown in light grey (CHRM and HIRHAM) are further discussed in the text. 
Table 1: Change of the active layer thickness due to independent and coupled temperature and precipitation changes. The values are rounded to the model resolution of $20 \mathrm{~cm}$.

\begin{tabular}{|l|c|c|c|}
\hline & May & August & October \\
\hline warm & $+60 \mathrm{~cm}$ & $+100 \mathrm{~cm}$ & $+80 \mathrm{~cm}$ \\
\hline cold & $-60 \mathrm{~cm}$ & $-80 \mathrm{~cm}$ & $-20 \mathrm{~cm}$ \\
\hline wet & $-40 \mathrm{~cm}$ & $\pm 0 \mathrm{~cm}$ & $-60 \mathrm{~cm}$ \\
\hline dry & $+20 \mathrm{~cm}$ & $\pm 0 \mathrm{~cm}$ & $-20 \mathrm{~cm}$ \\
\hline & & & \\
\hline warm and wet & $+60 \mathrm{~cm}$ & $+100 \mathrm{~cm}$ & $+80 \mathrm{~cm}$ \\
\hline warm and dry & $+80 \mathrm{~cm}$ & $+80 \mathrm{~cm}$ & $+80 \mathrm{~cm}$ \\
\hline cold and wet & $-80 \mathrm{~cm}$ & $-120 \mathrm{~cm}$ & $-80 \mathrm{~cm}$ \\
\hline cold and dry & $-20 \mathrm{~cm}$ & $-120 \mathrm{~cm}$ & $-60 \mathrm{~cm}$ \\
\hline
\end{tabular}

Table 2: Temperature and precipitation average in October for a period of the control run (1981-2003) and a period in the scenario run (2071-2093) in two different RCM data sets (a2bc and a2bh) which only differ in the used RCM (CHRM resp. HIRHAM). The last row gives the mean modelled snow depth in October by the CoupModel with the use of the given data sets.

\begin{tabular}{|l|c|c|c|}
\hline Data set & $\begin{array}{c}\text { Observations } \\
(1981-2003)\end{array}$ & $\begin{array}{c}\text { CHRM } \\
(2071-2093)\end{array}$ & $\begin{array}{c}\text { HIRHAM } \\
(2071-2093)\end{array}$ \\
\hline annual mean temperature & $-5 .{ }^{\circ} \mathrm{C}$ & $-2.4^{\circ} \mathrm{C}$ & $-2.2^{\circ} \mathrm{C}$ \\
\hline mean annual precipitation sum & $883 \mathrm{~mm}$ & $831 \mathrm{~mm}$ & $868 \mathrm{~mm}$ \\
\hline mean temperature in October & $-3.3^{\circ} \mathrm{C}$ & $0.0^{\circ} \mathrm{C}$ & $+1.2^{\circ} \mathrm{C}$ \\
\hline mean precipitation sum in October & $72 \mathrm{~mm}$ & $75 \mathrm{~mm}$ & $74 \mathrm{~mm}$ \\
\hline precipitation at temperatures $>0{ }^{\circ} \mathrm{C}$ & $2 \mathrm{~mm}$ & $50 \mathrm{~mm}$ & $40 \mathrm{~mm}$ \\
\hline precipitation at temperatures $\leq 0{ }^{\circ} \mathrm{C}$ & $70 \mathrm{~mm}$ & $24 \mathrm{~mm}$ & $34 \mathrm{~mm}$ \\
\hline $\begin{array}{l}\text { mean modelled snow depth in October } \\
\text { with the CoupModel }\end{array}$ & $37 \mathrm{~cm}$ & $4 \mathrm{~cm}$ & $7 \mathrm{~cm}$ \\
\hline
\end{tabular}

